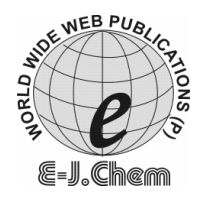

http://www.e-journals.net
ISSN: 0973-4945; CODEN ECJHAO

E-Journal of Chemistry 2010, 7(3), 807-812

\title{
Development and Validation of a Rapid RP-HPLC Method for the Estimation of Esmolol Hydrochloride in Bulk and Pharmaceutical Dosage Forms
}

\author{
VANITA SOMASEKHAR* and D. GOWRI SANKAR \\ *K.L.E University's College of Pharmacy, \\ II Block, Rajajinagar, Bangalore-560010, India. \\ College of Pharmaceutical Sciences, \\ Andhra University, Visakhapatnam-530003, India. \\ vanitasom@gmail.com
}

Received 8 January 2010; Accepted 5 March 2010

\begin{abstract}
A reverse phase HPLC method is described for the determination of esmolol hydrochloride in bulk and injections. Chromatography was carried on a $\mathrm{C}_{18}$ column using a mixture of acetonitrile, $0.05 \mathrm{M}$ sodium acetate buffer and glacial acetic acid $(35: 65: 3 \mathrm{v} / \mathrm{v} / \mathrm{v})$ as the mobile phase at a flow rate of $1 \mathrm{~mL} / \mathrm{min}$ with detection at $275 \mathrm{~nm}$. The retention time of the drug was $4.76 \mathrm{~min}$. The detector response was linear in the concentration of $1-50 \mu \mathrm{g} / \mathrm{mL}$. The limit of detection and limit of quantification was 0.614 and $1.86 \mu \mathrm{g} / \mathrm{mL}$ respectively. The method was validated by determining its sensitivity, linearity, accuracy and precision. The proposed method is simple, economical, fast, accurate and precise and hence can be applied for routine quality control of esmolol hydrochloride in bulk and injections.
\end{abstract}

Keywords: Esmolol hydrochloride, HPLC, Validation.

\section{Introduction}

Esmolol hydrochloride (ESM) (Molecular formula: $\mathrm{C}_{16} \mathrm{H}_{26} \mathrm{ClNO}_{4}$; Molecular weight: 331.835, methyl 3-\{4-[2-hydroxy-3-(isopropylamino) propoxy] phenyl\} propionate hydrochloride (Figure 1), is an ultra-short acting $\beta$-adrenergic receptor antagonist used for the rapid control of heart rate in patients with atrial fibrillation or atrial flutter. Since ESM is widely used in the rapid control of heart rate, it is important to develop and validate analytical methods for its determination in pharmaceutical dosage form. Review of literature has revealed that few methods have been reported for the estimation of esmolol hydrochloride. Most HPLC methods reported are useful in estimating esmolol hydrochloride in human plasma ${ }^{1-5}$ and 
biological fluids ${ }^{6}$. One method of estimation of esmolol hydrochloride by capillary electrophoresis has also been reported ${ }^{7}$. So far no systematic HPLC method has been reported for determination of ESM in pharmaceutical injections. This paper reports a rapid and sensitive HPLC method with UV detection, useful for routine quality control of ESM in pharmaceutical formulations. The method was validated by parameters such as linearity, accuracy, precision and robustness.

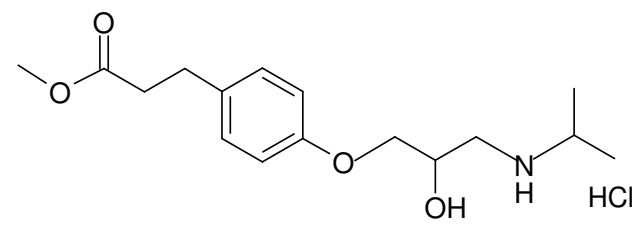

\section{Experimental}

Figure 1. Structure of esmolol hydrochloride.

The HPLC used consisted of Hitachi chromatographic system equipped with a Hitachi pump L-7110, Rheodyne universal injector 7725 and Hitachi L-7400 UV-visible detector. The chromatographic studies were performed using Varian ${ }^{\circledR}$ Microsorb-MV $100 \mathrm{C}_{18}, 5 \mu \mathrm{m}$, $250 \mathrm{~mm} \times 4.6 \mathrm{~mm}$ i.d. column, at ambient temperature. Peak area integration was performed using Winchrom software. A Shimadzu model 1700 double beam UV-visible spectrophotometer with a pair of $10 \mathrm{~mm}$ matched quartz cells was employed for determination of absorption maximum.

\section{Reagents and chemicals}

HPLC grade acetonitrile and glacial acetic acid were obtained from Rankem (Mumbai, India) and sodium acetate (A.R. grade) was obtained from Sd Fine Chemicals, Mumbai, India. Pure sample of drug was obtained from Claris Fine Chemicals, Ahmedabad, India. Ultra pure water obtained from Milli-Q academic system (Millipore Pvt. Ltd., Bangalore, India) was used to prepare all solutions for the method.

\section{Chromatographic conditions}

The process was carried out on $\mathrm{C}_{18}$ column $(5 \mu \mathrm{m}, 250 \times 4.6 \mathrm{~mm}$, i.d) using the mobile phase consisting of acetonitrile, $0.05 \mathrm{M}$ sodium acetate buffer and glacial acetic acid in the ratio 35:65:3 v/v/v respectively at a flow rate of $1 \mathrm{~mL} / \mathrm{min}$. Wavelength was fixed at 275 $\mathrm{nm}$. The mobile phase was filtered through $0.45 \mu \mathrm{m}$ membrane filter and degassed.

\section{Preparation of solutions}

Stock standard solution of the pure drug was prepared by dissolving $100 \mathrm{mg}$ of ESM in $100 \mathrm{~mL}$ volumetric flask using water. Then the volume was made up to the mark with the same solvent to give a final concentration of $1000 \mu \mathrm{g} / \mathrm{mL}$. Standard solutions of ESM (1.0, 2.5, 5.0, 10.0, 20.0, 30.0, 40.0 and $50.0 \mu \mathrm{g} / \mathrm{mL}$ ) were prepared by subsequent dilution with mobile phase.

\section{Validation}

Three series of standard calibration solutions in the range of $1.0-50.0 \mu \mathrm{g} / \mathrm{mL}$ were prepared and analyzed as described above. Calibration curves were constructed using three series of standard ESM solutions in the range of 1.0 to $50.0 \mu \mathrm{g} / \mathrm{mL}$. Peak area was recorded for all the peaks and a calibration graph was obtained by plotting peak area versus concentration of ESM (Figure 2). To establish the accuracy and intra-day and inter-day precision of the method, six replicate solutions at three different concentrations $(10.0,20.0,40.0 \mu \mathrm{g} / \mathrm{mL})$ were assayed on single day and three separate days. 


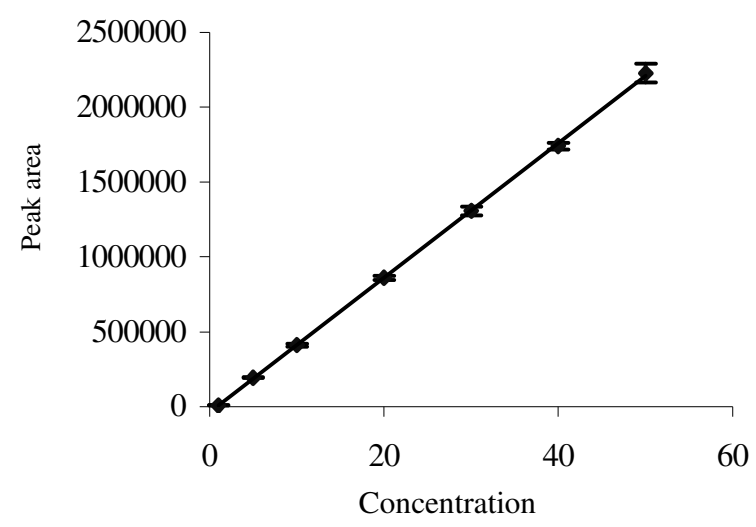

\section{Assay method}

Figure 2. Calibration curve.

The sample solution was prepared by diluting $10 \mathrm{~mL}$ of Esocard injection equivalent to 100 $\mathrm{mg}$ of ESM to $100 \mathrm{~mL}$ with water in a $100 \mathrm{~mL}$ volumetric flask. $1 \mathrm{~mL}$ and $2 \mathrm{~mL}$ of this solution were further diluted to $100 \mathrm{~mL}$ with the mobile phase. $20 \mu \mathrm{L}$ of solution was injected into the HPLC system to obtain the chromatograms for the standard drug solution and the sample solution.

A steady baseline was recorded with the optimized chromatographic conditions. The standard solution of ESM was injected and the chromatogram recorded. The retention time of ESM was found to be $4.76 \mathrm{~min}$. The sample solution prepared from the injection was then injected and the amount of drug present was calculated from the calibration curve.

\section{Results and Discussion}

\section{Chromatographic conditions}

Sodium acetate buffer in the concentration range of 0.02 to $0.1 \mathrm{M}$ was studied and $0.05 \mathrm{M}$ was selected as it gave the best peak shape, retention time and least tailing. Various compositions of mobile phase consisting of acetonitrile and sodium acetate buffer $(0.05 \mathrm{M})$ (10:90 to 50:50) were used in the study and the composition of 35:65 was selected as it gave best elution, reasonable retention time and least tailing. Addition of glacial acetic acid was found to improve the peak shape. The typical chromatograms obtained for the standard and the injection sample are presented in Figure 3 (A) and (B) respectively.

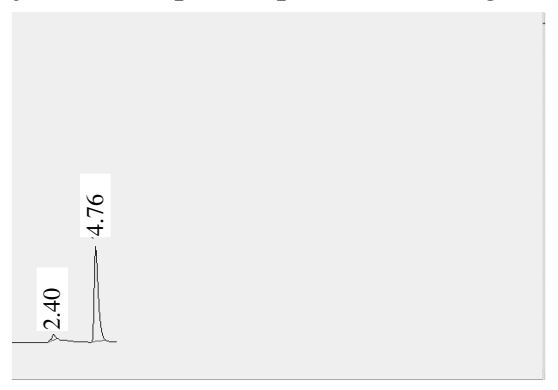

(A)

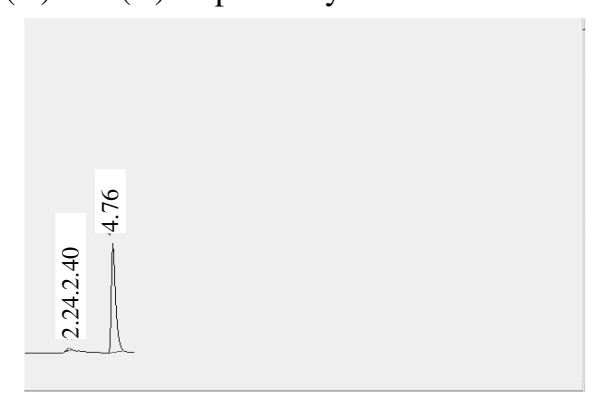

(B)

Figure 3(A). Chromatograms of esmolol hydrochloride standard solution $(10 \mu \mathrm{g} / \mathrm{mL})$ and (B) Esmolol hydrochloride in pharmaceutical dosage forms. 


\section{Linearity}

Calibration curves were constructed using three series of standard ESM solutions in the range of 1.0 to $50.0 \mu \mathrm{g} / \mathrm{mL}$. The equation of linear regression and statistical data are presented in Table 1 . The linearity of the calibration curve was validated by the high value of the correlation coefficient $(\mathrm{r}=0.9999)$.

Table 1. Statistical data of calibration curves of esmolol hydrochloride.

\begin{tabular}{lc}
\hline \multicolumn{1}{c}{ Parameters } & $\begin{array}{c}\text { Venlafaxine } \\
\text { Hydrochloride }\end{array}$ \\
\hline Linearity & $1-50 \mu \mathrm{g} / \mathrm{mL}$ \\
Regression equation & $Y=44952 \mathrm{x}-38239$ \\
Standard deviation of slope & 926.06 \\
Relative standard deviation of slope, $\%$ & 2.06 \\
Standard deviation of intercept & 8363.48 \\
Correlation coefficient (r) & 0.9999 \\
Limit of Detection (LOD), $\mu \mathrm{g} / \mathrm{mL}$ & $0.614 \mu \mathrm{g} / \mathrm{mL}$ \\
Limit of Quantitation (LOQ), $\mu \mathrm{g} / \mathrm{mL}$ & $1.86 \mu \mathrm{g} / \mathrm{mL}$ \\
\hline
\end{tabular}

\section{Limit of detection (LOD) and limit of quantification (LOQ)}

The limit of detection and the limit of quantification are defined as LOD $=3.3 \mathrm{\sigma} / \mathrm{s}$ and LOQ $=10 \sigma / \mathrm{s}$ respectively, where $\sigma$ denotes standard deviation of $y$-intercepts of regression lines and s denotes slope of the corresponding calibration curve ${ }^{7}$. The limit of detection was determined as $0.614 \mu \mathrm{g} / \mathrm{mL}$. The limit of quantification was determined as $1.86 \mu \mathrm{g} / \mathrm{mL}$.

\section{Precision}

The assay was investigated with respect to system suitability test, method precision and intermediate precision. The system suitability test and method precision were carried out to monitor repeatability and reproducibility.

In order to measure repeatability of the system (system suitability test), six consecutive injections were made and the results were evaluated by considering peak area values of ESM. The precision values with their R.S.D. are shown in Table 2. The results in Table 2 indicate that the R.S.D. (\%) is less than $2 \%$.

Three different concentrations of ESM were analyzed in three independent series in the same day (intra-day precision) and three consecutive days (inter-day precision), within each series every sample was injected six times. The R.S.D. values of intra- and inter-day studies (Table 2) varied from 0.12 to $0.53 \%$ showing that the intermediate precision of the method was satisfactory.

Table 2. Precision and accuracy of method for determination of esmolol hydrochloride $(\mathrm{n}=18$; six sets for $\mathbf{3 d})$.

\begin{tabular}{cccc}
\hline $\begin{array}{c}\text { Concentration } \\
\text { Taken, } \mu \mathrm{g} / \mathrm{mL}\end{array}$ & $\begin{array}{c}\text { Concentration found } \\
(\text { mean } \pm \text { S.D. }), \mu \mathrm{g} / \mathrm{mL}\end{array}$ & $\begin{array}{c}\text { Precision }^{\mathrm{a}} \\
(\mathrm{R} . S . \mathrm{D}, \%)\end{array}$ & $\begin{array}{c}\text { Accuracy }^{\mathrm{b}} \\
(\text { bias \%) }\end{array}$ \\
\hline $\begin{array}{c}\text { Intra-day }(\mathrm{n}=6) \\
10.0\end{array}$ & $10.03 \pm 0.053$ & 0.53 & 0.3 \\
20.0 & $20.04 \pm 0.053$ & 0.28 & 0.2 \\
40.0 & $39.88 \pm 0.082$ & 0.22 & 0.3 \\
Inter-day $(\mathrm{n}=18)$ & $10.06 \pm 0.029$ & 0.29 & 0.6 \\
10.0 & $20.01 \pm 0.048$ & 0.23 & 0.05 \\
20.0 & $39.95 \pm 0.043$ & 0.12 & 0.125 \\
40.0 & \multicolumn{3}{c}{}
\end{tabular}




\section{Accuracy and recovery studies}

The accuracy of a method is expressed as the closeness of agreement between the value found and the value that is accepted as a reference value. It is determined by calculating the percent difference (bias\%) between the measured mean contents and the corresponding nominal contents ${ }^{8}$. Table 2 shows the results obtained for intra- and inter-day accuracy.

The accuracy of the proposed method was also tested by recovery experiments. Recovery experiments were performed by taking different sample concentrations and spiking with ESM at two different concentration levels (50\% and 100\% ESM). Five samples were prepared for each recovery level. Samples were treated as described in the procedure for sample preparations. The results obtained are shown in Table 3, from which it is clear that both the recoveries and repeatabilities are excellent.

Table 3. Recovery data for the proposed RP-HPLC method ( $n=5)$.

\begin{tabular}{cccccc}
\hline Drug & Level & $\begin{array}{c}\text { Amount of sample } \\
\text { taken, } \mu \mathrm{g} / \mathrm{mL}\end{array}$ & $\begin{array}{c}\text { Amount of } \\
\text { standard } \\
\text { recovered, } \mu \mathrm{g} / \mathrm{mL}\end{array}$ & $\begin{array}{c}\text { Recovery, } \\
\%\end{array}$ & $\begin{array}{c}\text { R.S.D, } \\
\%\end{array}$ \\
\hline $\begin{array}{c}\text { Esmolol } \\
\text { hydrochloride }\end{array}$ & I & 10 & 4.97 & 99.8 & 0.299 \\
& II & 10 & 10.00 & 100.0 & 0.232 \\
& III & 20 & 10.03 & 100.1 & 0.144 \\
& IV & 20 & 20.00 & 100.01 & 0.125 \\
\hline
\end{tabular}

\section{Robustness}

Robustness relates to the capacity of the method to remain unaffected by small but deliberate variations introduced into the method parameters. Influences of small changes in the mobile phase composition $( \pm 10 \%)$ and flow rate $( \pm 10 \%)$ were studied to determine robustness of the method. Peak areas and retention time changes were observed. Peak area values and retention time values varied by less than $2 \%$. Despite the changes in retention time there was no problem for quantification.

\section{Analytsis of pharmaceutical formulation}

In order to evaluate the applicability and reliability of the proposed methodology, it was applied to the determination of ESM in injections. Satisfactory results were obtained and were found to be in agreement with label claims (Table 4).

Table 4. Analysis of esmolol hydrochloride from pharmaceutical formulations by proposed method.

\begin{tabular}{cccc}
\hline Formulations & $\begin{array}{c}\text { Labelled } \\
\text { amount, mg }\end{array}$ & $\begin{array}{c}\text { Amount found* } \\
\pm \text { S.D. }\end{array}$ & $\begin{array}{c}\text { \% Recovery } \pm \\
\text { R.S.D. }\end{array}$ \\
\hline Injection I & 10 & $10.04 \pm 0.057$ & $100.45 \pm 0.573$ \\
Injection II & 10 & $10.01 \pm 0.024$ & $100.10 \pm 0.245$ \\
Injection III & 10 & $10.00 \pm 0.052$ & $100.02 \pm 0.515$ \\
Injection IV & 10 & $10.00 \pm 0.012$ & $100.03 \pm 0.121$ \\
\hline
\end{tabular}

\section{Conclusion}

The proposed high-performance liquid chromatographic method has been evaluated for linearity, precision, accuracy, specificity and proved to be convenient and effective for the quality control of esmolol hydrochloride in given application. The measured signal was 
shown to be precise, accurate and linear over the concentration range tested $(1.0-50.0 \mu \mathrm{g} / \mathrm{mL})$ with a correlation coefficient better than 0.9999. Moreover, the lower solvent consumption leads to a cost effective and environmentally friendly chromatographic procedure. Thus, the proposed methodology is rapid, selective, requires a simple sample preparation procedure and represents a good procedure of esmolol hydrochloride determination in pharmaceutical dosage forms.

\section{Acknowledgment}

The authors thank M/s Claris Fine Chemicals, Mumbai, India for providing the pure drug to develop the method and Dr. B.G.Desai, Principal of K.L.E University's College of Pharmacy, Bangalore for providing support and necessary research facilities.

\section{References}

1. $\quad$ Tang Y, He Y, Yao T and Zeng S, J Chromatogr B., 2004, 805, 249-254.

2. $\quad$ Tang Y, He Y, Yao T and Zeng S, J Biochem Biophys Methods, 2004, 59, 159-166.

3. Maurer H H, Tenberken O, Kratzsch C, Weber A A and Peters F T, J Chromatogr A., 2004, 1058(1-2), 169-181.

4. Zuppa A F, Shi, Adamson H and Peter C, J Chromatogr B., 2003, 796(2), 293-301.

5. $\quad$ Achari R, Drissel D and Hulse J D, Clin Chem., 1986, 32(2), 374-376.

6. Malovaná S, Gajdošová D, Benedik J and Havel J, J Chromatogr B., 2001, 760(1), 37-43.

7. ICH-Q2B Validation of Analytical Procedures: Methodology International Conference on Harmonization of Technical Requirements for Registration of Pharmaceuticals for Human Use, Geneva, Switzerland, 1996.

8. Braggio S, Barnaby R J, Grossi P and Cugola M, J Pharm Biomed Anal., 1996, 14, 375-388. 


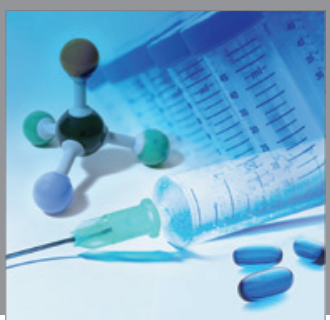

International Journal of

Medicinal Chemistry

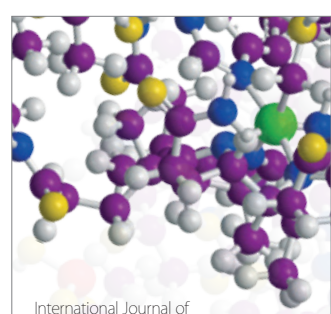

Carbohydrate Chemistry

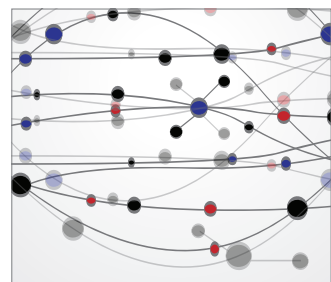

The Scientific World Journal
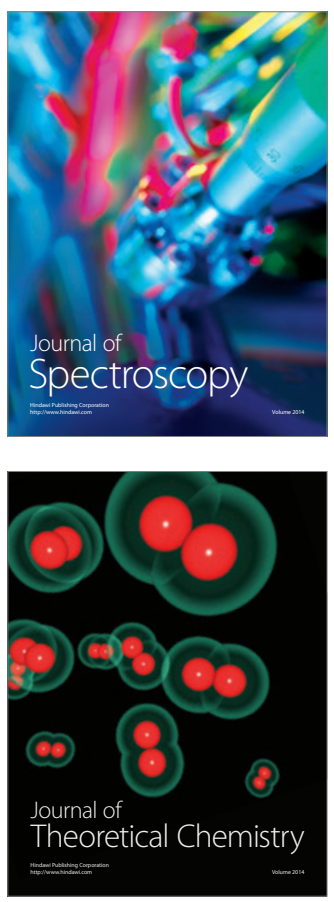
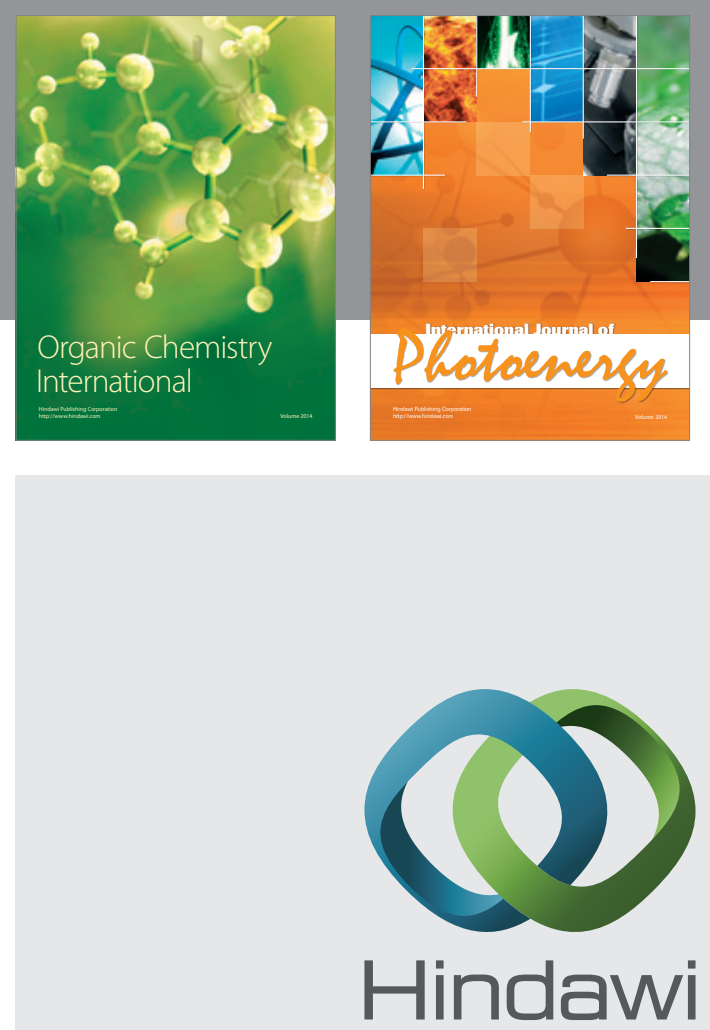

Submit your manuscripts at

http://www.hindawi.com
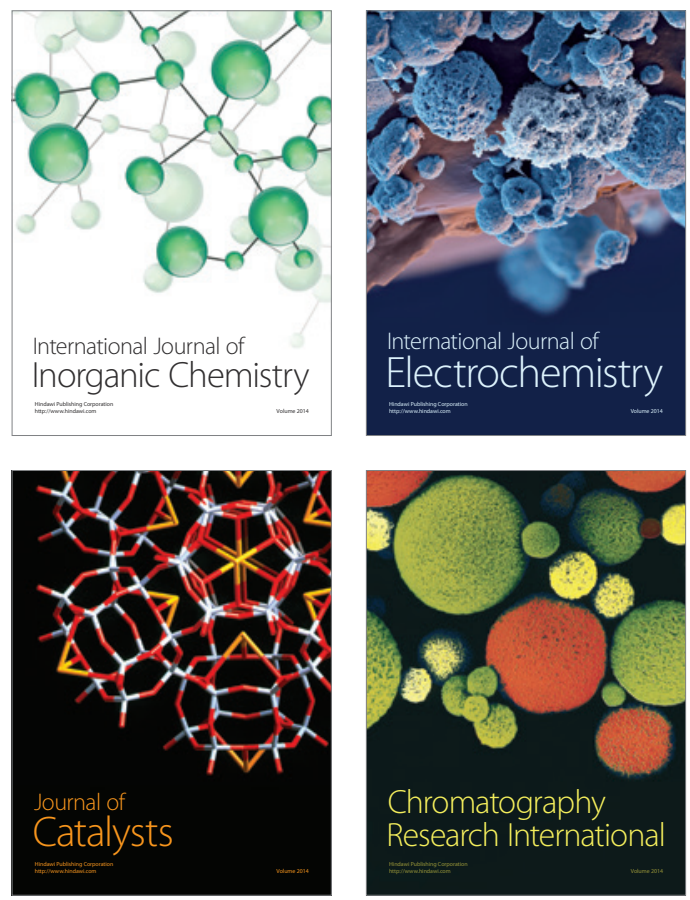
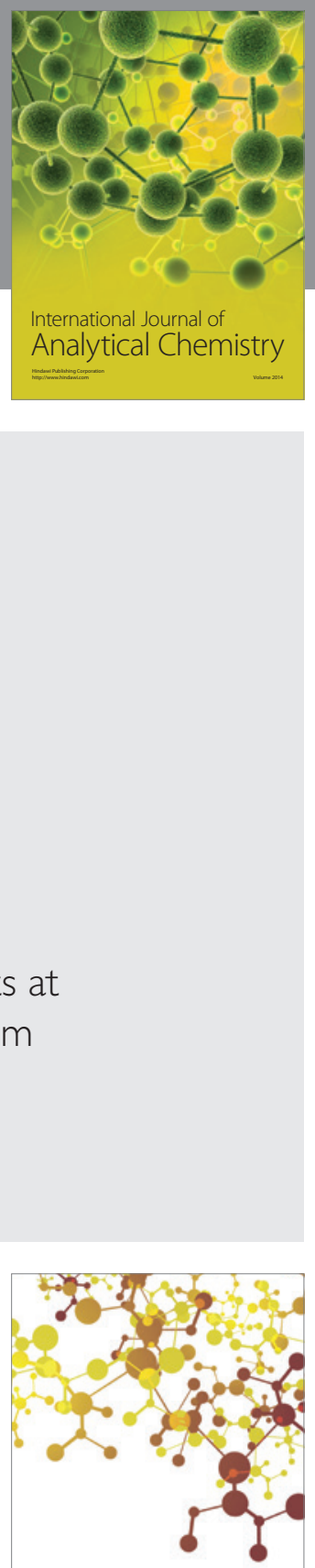

Journal of

Applied Chemistry
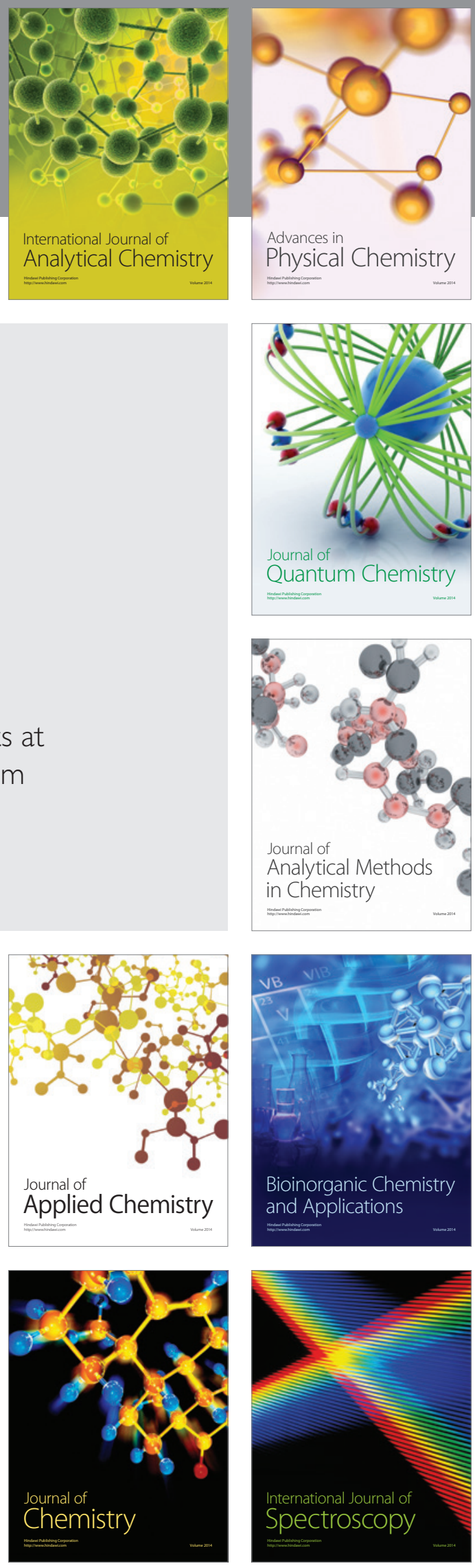